\title{
Technology-enabled division of labour: the use of handhelds
}

\section{Jos Benders}

Catholic University of Leuven,

Centre for Sociological Research (CESO),

Parkstraat 45, P.O. Box 3601, B-3000 Leuven, Belgium

E-mail: jos.benders@soc.kuleuven.be

and

Tilburg University,

Organization Studies,

P.O. Box 90153, NL-5000 LE Tilburg, The Netherlands

\section{Roel Schouteten}

Nijmegen School of Management, Institute for Management Research, Radboud University Nijmegen,

P.O. Box 9108, NL-6500 HK Nijmegen,

The Netherlands

E-mail: r.schouteten@fm.ru.nl

\section{Céline de Ruijsscher}

Talis, P.O. Box 628, NL-6500 AP Nijmegen,

The Netherlands

E-mail: celine.deruijsscher@talis.nl

\begin{abstract}
Using the task pool model and data from 15 establishments in the Dutch hospitality industry, this study shows how and why applying handhelds affects the division of labour. These devices allow to split the waiters' jobs into separate tasks which tend to be combined into two separate "sub jobs": the "palmtopper" and the "runner". Whereas handhelds are not necessary for creating separate waiting jobs, the technology enables to create conditions under which it becomes attractive for management to opt for an increased division of labour. We show the contingent conditions and underlying mechanisms which explain why certain choices prevail.
\end{abstract}

Keywords: case study; division of labour; electronic ordering systems; e-finance; handhelds; hospitality industry; mobile payment systems; the Netherlands; social voluntarism; technological determinism.

Reference to this paper should be made as follows: Benders, J., Schouteten, R. and de Ruijsscher, C. (2012) 'Technology-enabled division of labour: the use of handhelds', Int. J. Electronic Finance, Vol. 6, No. 2, pp. 184-197. 
Biographical notes: Jos Benders (1965) holds the Chair Organisation Concepts at Tilburg University (the Netherlands) and is a Guest Professor at the Centre for Sociological Research of the Catholic University of Leuven (Belgium). His research interests include (fashionable) organisation concepts, new technology in organisations, lean health care, self-directed work-teams and late medieval coinage in the Low Countries. He is co-author and author of a wide range of publications and published in such journals as Human Relations, Information and Management, Journal of Management Studies, Numismatic Chronicle and Organization.

Roel Schouteten is Assistant Professor in Strategic Human Resource Management and member of the Institute of Management Research, Radboud University Nijmegen, the Netherlands. His research interests include quality of working life, especially in relation to organisational and job design and in relation to individual and organisational performance. He takes special interest in the interplay of technology, work (design), performance and quality of working life and also in high performance work systems. He is an editor of the Dutch journal Tijdschrift voor Arbeidsvraagstukken (Journal of Labour Studies).

Céline de Ruijsscher wrote her Master thesis on the influence of Handhelds on job design in the hospitality industry. After graduation she continued her interest in technology and labour organisation as a consultant on Human Resources and ERP systems in the Information technology branch. Currently she is a business consultant on Social Housing and ERP systems.

\section{Introduction}

Whereas handhelds have become so widely used in organisations that they may be regarded as common technology and are taken for granted, the opposite holds true for studies on their actual use in work processes. Extensive literature searches yielded no papers into how these devices are actually deployed within organisations and what that means for the intra-organisational division of labour. That finding fits in a broader pattern, namely the relative neglect of studies into the uses of technologies (Barley and Kunda, 2001). There is an abundance of studies about the design (Caus et al., 2009; Lingfen et al., 2010) or the acceptance and use of electronic or mobile systems (Bouwman and Van de Wijngaert, 2009; Gerpott and Kornmeier, 2009), using theories that try to explain the processes underlying the acceptance and adoption of technology (Bayerl, 2010), but these fail to address work organisation and job structure issues.

Orlikowski and Scott (2008, pp.435-436) mention several reasons for this sorry state of affairs:

- the growing complexity and specialisation of organisational life that requires detailed investigation

- a general belief that technology is simply part of the institutional infrastructure and, as a result, taken for granted

- the growing complexity, speciality and rapid change in technological systems making it difficult to track and analyse them in detail. 
However, as they and others argue, any effects attributed to a technology are results of how that technology is designed, deployed, used and interpreted (Barley and Kunda, 2001, p. 79). The commonly occurring contradictory findings of studies on technologies' impacts can often be explained by looking into different uses of a particular technology. Our study on the use of handhelds follows this reasoning. We researched to what extent the introduction of handheld devices in the hospitality sector affected in the division of labour and more specifically the job of the waiter. We show how the deployment of handhelds and the related job changes can only be understood in the local context of use where a host of interacting factors play. Choosing a relatively straightforward context of use enabled us to come to grips with the interacting factors that together decided how and why, at a given moment the handhelds are actually deployed.

As a starting point for our study, we used the so-called 'task pool model' which details theoretically how a technology system may be expected to affect jobs (section two). Next, we discuss handhelds as technology. We proceed with our methodological approach. In the fourth section we present our results. We finish our paper by formulating our conclusions and discussion them.

\section{Task pool model}

Central in our study is the 'task pool model' (Benders, 1993). This model presents an intermediate position in the classical debates on the influence of a specific technology on the division of labour, of old, two polar positions are conventionally distinguished: technological determinism and voluntarism (Grint and Woolgar, 1997). Technological determinism is the view that technology's effects on social life are determining and inevitable, whereas voluntarists argue that there are many elements of choice into how technologies are being used. This position may be taken in extremis, i.e., that the technology itself does not matter and that any effects resulting from its use are purely socially determined (Orlikowski and Scott, 2008, p. 451). The task pool model leaves from a given technology, which is posited to affect the 'task pool', i.e., those tasks that (still) have to be performed by humans. Job design is a matter of combining the tasks into jobs and represents the voluntarism in the model. Designing jobs occurs, implicitly or explicitly, via 'design orientations'. The two contrasting positions are 'fractionized' and 'integrative'. According to the fractionized design orientation tasks have to be split over different jobs and the resulting division of labour is thus high. The integrative perspective tries to combine controlling and operational tasks into complete tasks consisting of a coherent set of executing, preparing and supporting tasks with varying levels of difficulty (Hacker, 1989) allowing job holders to control their work. This results in a desirable balance between job demands and decision latitude (Karasek, 1979) and a lower degree of division of labour.

The main role of the technical system in the task pool model is that its introduction influences the composition of the task pool. New systems tend to mechanize tasks that were previously conducted manually c.q. by humans. A second change is that the novel systems need to be operated, leading to additional operating tasks (cf. Davis and Taylor, 1976, p. 388). Figure 1 presents this reasoning graphically.

When the newly composed task pool consists of tasks of varying degree of difficulty, one can expect that jobs of different levels are created. In general the more mundane tasks, for instance, machine feeding, are combined into a job, as are the more complex ones, such as machine maintenance. The logic behind such a grouping is that job holders tend to get paid 
Figure 1 The influence of technical systems on job design

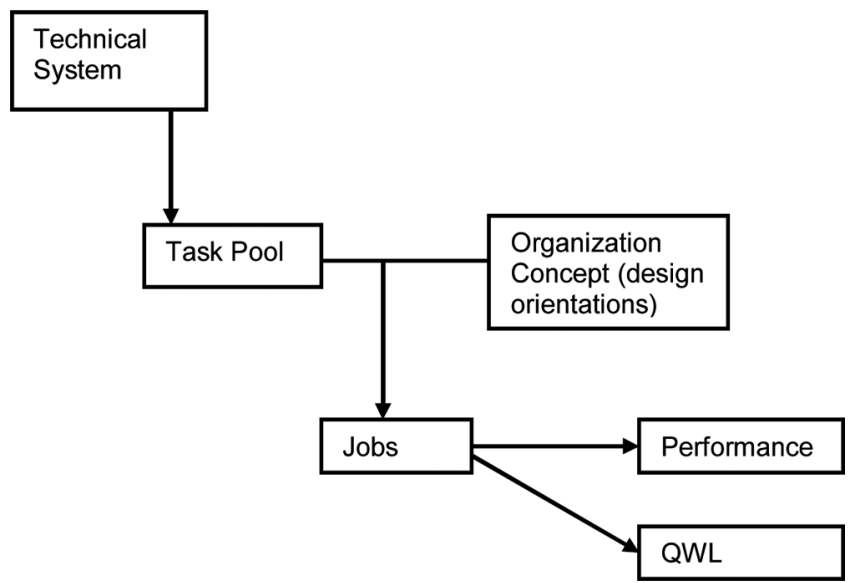

based on the highest needed qualification. When the simpler tasks are split from a job, a new and lower paid job can be created. Thus, economizing of labour cost is an important driver behind a fractionized job structure.

\section{Handhelds}

A handheld computer or 'Personal Digital Assistant'(PDA) may be defined as 'a computerized machine that is designed to be held in one hand' (Myers, 2005, p. 252). Handhelds are generally purchased as an extension of an existing bar automation system. These may be less or more advanced, ranging from simple cash registers to 'establishment wide systems' including automatic tapping systems and stock control. Handheld providers claim a number of advantages on their websites (De Ruijsscher and Victoria, 2006):

- $\quad$ saving time (faster delivery)

- $\quad$ more service

- $\quad$ higher sales

- lower costs

- $\quad$ task simplification

- $\quad$ efficiency (in general)

- improved control

- less mistakes

- $\quad$ quality of work life.

Dominant in the list are (sometimes interrelated) economic arguments. Faster delivery means a higher table turnaround and thus higher sales and at the same time cost savings as waiters no longer need to walk to the bar to pass an order. Improved control, both in terms of less mistakes and more tight supervision over waiters, is only mentioned 
occasionally, i.e., in 10 to 15 percent of the websites. Simplification of work and tasks scored slightly higher. Quality of working life was mentioned least of all motives. Scornavacca et al. (2006, p. 560) mention 'the efficiency of the ordering process' as most important advantage. This may come about by deploying "less and less qualified staff" (cost saving).

This list of proposed advantages raises the question how these intended effects are to be achieved. An answer to this question requires insight in how waiting tasks are combined into or divided over jobs and what job structures are possible in restaurants and bars.

\subsection{Possible job structures}

Conventionally, waiters job consists of three main tasks: taking orders, delivering them and settling the account. Operating the handheld is a new task as a result of the introduction of a new technology. Handling handhelds is not complex, yet some 'computer literacy' is necessary and hence some instruction is required.

When taken, orders are fed into the handheld. The order is automatically passed to the bar (or kitchen), where the drinks and or food are prepared. Drinks may eventually be poured instantaneously and delivered to the appropriate table. Pouring drinks c.q. preparing orders is normally a separate job, namely that of the 'bar person' or kitchen help (cook). Bills are usually paid when the customers are about to leave, when the total amount can be generated per table/customer.

The introduction of the handhelds allows splitting the main three tasks over different jobs. The waiter's job may be split into two separate ones: 'palmtoppers' and 'runners'. The former takes orders and cashes the payment. The latter only delivers orders. Analytically, we thus distinguish between an integrated waiting job, in which a waiter performs all the main tasks (option I) and a separation of palmtopper and runner (option S).

\section{Methodology}

A total of 15 establishments in the hospitality industry that use handhelds were researched. The selection of the establishments was based on the desirably rich diversity of factors that might influence choices concerning job structure when using handhelds. As a result, different kinds of establishments (lunch room, pub, grand café, restaurant) are represented in the dataset; the idea is that different kinds of establishments use a different client approach, resulting in different job structures. Furthermore, we included establishments of different sizes, because work organisation depends on the amount of work. Moreover, in larger establishments there may be less handhelds available than there are employees. Finally, the choice to include establishments in different Dutch cities was based on convenience sampling; most are located in Nijmegen (a middle sized Dutch city - 165,000 inhabitants with a large student population), but we wanted to prevent that specific city characteristics, such as the availability of students on the labour market, would influence our results. Table 1 presents an overview of the establishments and their most important characteristics in our research.

Interviews with employees (mostly managing employees), based on a structured interview guide on the character of the establishment, the kind of handheld (use) and changes in job structure, were transcribed and subjected to a respondent check. We also asked for information about the implicit or explicit choices around the purchase and introduction of the handhelds. 
In addition, mainly prior to the interviews, casual observations while visiting bars generated an expected richness of aspects playing a role in using this relatively simple technology. This information was used in the interviews to ask for background information to our observations.

\section{Results}

\subsection{Job structure}

Separation as the standard job structure (option S) was found in almost all investigated establishments (see Table 1). A first conclusion then is that the potential inherent in handheld use for increasing the division of labour is almost always actually used.

Table 1 Overview of the cases in the study

\begin{tabular}{|c|c|c|c|c|c|}
\hline Case & Location & $\begin{array}{l}\text { Establishment } \\
\text { characteristics }\end{array}$ & Handheld use & Adoption reason & Job structure \\
\hline ET & Tilburg & Pub, with terrace, & $\begin{array}{l}\text { By } \\
\text { experienced } \\
\text { staff }\end{array}$ & $\begin{array}{l}\text { Ease/comfort, } \\
\text { improved service, } \\
\text { time saving }\end{array}$ & $\begin{array}{l}\text { Separation of } \\
\text { jobs between } \\
\text { palmtoppers } \\
\text { and runners, job } \\
\text { rotation, runner } \\
\text { allowed to take } \\
\text { small orders, } \\
\text { runners are senior } \\
\text { staff and take role } \\
\text { of host(ess) }\end{array}$ \\
\hline EN & Nijmegen & $\begin{array}{l}\text { Pub ( } 70 \text { seats }), \\
\text { terrace }(150-200 \\
\text { seats })\end{array}$ & $\begin{array}{l}\text { Only outside } \\
\text { (in summer), } \\
\text { by experienced } \\
\text { staff }\end{array}$ & $\begin{array}{l}\text { Use by } \\
\text { competitors, } \\
\text { information in } \\
\text { trade journal, } \\
\text { intended peace } \\
\text { and quiet, } \\
\text { intended faster } \\
\text { delivery }\end{array}$ & $\begin{array}{l}\text { Separation of } \\
\text { jobs between } \\
\text { palmtoppers and } \\
\text { runners, but only } \\
\text { for outside use in } \\
\text { the summer, job } \\
\text { rotation }\end{array}$ \\
\hline DG & Groningen & $\begin{array}{l}19 \text { bars in three } \\
\text { separate but } \\
\text { interlinked } \\
\text { pubs, terrace } \\
\text { ( } 600 \text { seats), in } \\
\text { shopping area }\end{array}$ & $\mathrm{NA}$ & NA & $\begin{array}{l}\text { Separation of } \\
\text { jobs between } \\
\text { palmtoppers and } \\
\text { runners, more } \\
\text { people needed than } \\
\text { before }\end{array}$ \\
\hline FD & Doetinchem & NA & $\begin{array}{l}\text { Inside and } \\
\text { outside by } \\
\text { experienced } \\
\text { staff who take } \\
\text { the role of } \\
\text { host(ess) }\end{array}$ & Saving time & $\begin{array}{l}\text { Separation of } \\
\text { jobs between } \\
\text { palmtoppers } \\
\text { and runners, } \\
\text { experienced staff } \\
\text { works behind the } \\
\text { bar (because of } \\
\text { increased pressure) }\end{array}$ \\
\hline
\end{tabular}


Table 1 Overview of the cases in the study (continued)

\begin{tabular}{|c|c|c|c|c|c|}
\hline Case & Location & $\begin{array}{l}\text { Establishment } \\
\text { characteristics }\end{array}$ & Handheld use & Adoption reason & Job structure \\
\hline DU & Arnhem & NA & $\begin{array}{l}\text { By } \\
\text { experienced } \\
\text { staff }\end{array}$ & Faster service & $\begin{array}{l}\text { Separation of } \\
\text { jobs between } \\
\text { palmtoppers } \\
\text { and runners, } \\
\text { experienced staff } \\
\text { works behind the } \\
\text { bar (because of } \\
\text { increased pressure) }\end{array}$ \\
\hline DA & Amsterdam & $\begin{array}{l}\text { Café/Restaurant } \\
\text { (240 seats) }\end{array}$ & $\begin{array}{l}\text { By } \\
\text { experienced } \\
\text { staff } \\
\text { (especially in } \\
\text { busy times) }\end{array}$ & Faster service & $\begin{array}{l}\text { Separation of } \\
\text { jobs between } \\
\text { palmtoppers and } \\
\text { runners }\end{array}$ \\
\hline $\mathrm{K}$ & Nijmegen & $\begin{array}{l}\text { Lunch room } \\
\left(60 \mathrm{~m}^{2}\right), \text { terrace } \\
\left(100 \mathrm{~m}^{2}, 30\right. \\
\text { tables }) \text { separated } \\
\text { from the pub by } \\
\text { foot path, outside } \\
\text { shopping area, } \\
\text { extended lunch } \\
\text { menu, no dinner } \\
\text { menu }\end{array}$ & $\begin{array}{l}2 \text { handhelds, } \\
\text { during } \\
\text { summer, inside } \\
\text { and outside }\end{array}$ & $\begin{array}{l}\text { Faster service at } \\
\text { large terrace }\end{array}$ & $\begin{array}{l}\text { Separation of } \\
\text { jobs between } \\
\text { palmtoppers and } \\
\text { runners, job rotation } \\
\text { (even during a } \\
\text { working day) }\end{array}$ \\
\hline VA & Nijmegen & $\begin{array}{l}\text { Pub }\left(210 \mathrm{~m}^{2}\right) \text { and } \\
\text { brasserie }\left(230 \mathrm{~m}^{2}\right) \text {, } \\
\text { terrace }\left(50 \mathrm{~m}^{2}\right), \\
\text { in shopping } \\
\text { area, extended } \\
\text { more expensive } \\
\text { menu in } \\
\text { brasserie, limited } \\
\text { cheaper menu } \\
\text { in pub, owner } \\
\text { and investors } \\
\text { aim at profit } \\
\text { maximization }\end{array}$ & $\begin{array}{l}3 \text { handhelds } \\
\text { in each } \\
\text { establishment, } \\
\text { linked to } \\
\text { automated bar } \\
\text { system, all } \\
\text { year round, } \\
\text { inside and } \\
\text { outside }\end{array}$ & $\begin{array}{l}\text { Faster service } \\
\text { inside, control, } \\
\text { modern image, } \\
\text { increased sales }\end{array}$ & $\begin{array}{l}\text { Separation of } \\
\text { jobs between } \\
\text { palmtoppers and } \\
\text { runners, job rotation } \\
\text { (even during a } \\
\text { working day), } \\
\text { runners are allowed } \\
\text { to take small orders } \\
\text { and enter into the } \\
\text { system at the cash } \\
\text { desk }\end{array}$ \\
\hline $\mathrm{DC}$ & Nijmegen & $\begin{array}{l}\text { Grand café } \\
\left(150 \mathrm{~m}^{2}\right) \text {, terrace } \\
\left(75 \mathrm{~m}^{2}\right) \text {, in } \\
\text { shopping area, } \\
\text { lunch and dinner } \\
\text { menu limited to } \\
10 \text { main dishes }\end{array}$ & $\begin{array}{l}2 \text { handhelds, } \\
\text { all year round, } \\
\text { inside and } \\
\text { outside, by } \\
\text { senior staff (as } \\
\text { control) }\end{array}$ & $\begin{array}{l}\text { Faster service in } \\
\text { side, efficiency, } \\
\text { better service, } \\
\text { theft prevention, } \\
\text { increased sales }\end{array}$ & $\begin{array}{l}\text { Separation of } \\
\text { jobs between } \\
\text { palmtoppers and } \\
\text { runners, job rotation } \\
\text { (even during a } \\
\text { working day), } \\
\text { experienced staff } \\
\text { works behind the } \\
\text { bar (because of } \\
\text { increased pressure) }\end{array}$ \\
\hline
\end{tabular}


Table 1 Overview of the cases in the study (continued)

\begin{tabular}{|c|c|c|c|c|c|}
\hline Case & Location & $\begin{array}{l}\text { Establishment } \\
\text { characteristics }\end{array}$ & Handheld use & Adoption reason & Job structure \\
\hline LF & Nijmegen & $\begin{array}{l}\text { Café/restaurant } \\
\left(150 \mathrm{~m}^{2}\right) \text {, terrace } \\
\left(50 \mathrm{~m}^{2}\right) \text { which is } \\
\text { split in two parts } \\
\text { and separated by } \\
\text { a road, outside } \\
\text { shopping area, } \\
\text { extended menu } \\
\text { for lunch and } \\
\text { dinner ( } 20 \text { starters, } \\
20 \text { main dishes, } \\
9 \text { deserts) }\end{array}$ & $\begin{array}{l}2 \text { handhelds, } \\
\text { during } \\
\text { summer, only } \\
\text { outside }\end{array}$ & $\begin{array}{l}\text { Faster service } \\
\text { at large terrace, } \\
\text { reduction physical } \\
\text { work load }\end{array}$ & $\begin{array}{l}\text { Separation of } \\
\text { jobs between } \\
\text { palmtoppers and } \\
\text { runners, job rotation } \\
\text { (even during a } \\
\text { working day), } \\
\text { runners are senior } \\
\text { staff and take role } \\
\text { of host(ess) }\end{array}$ \\
\hline DH & Nijmegen & $\begin{array}{l}\text { Brewery with } \\
\text { separated } \\
\text { pub }\left(100 \mathrm{~m}^{2}\right) \\
\text { and restaurant } \\
\left(100 \mathrm{~m}^{2}\right) \text { served } \\
\text { by same bar, } \\
\text { terrace }\left(175 \mathrm{~m}^{2}\right) \text {, } \\
\text { combined } \\
\text { with brewery } \\
\text { shop (staff has } \\
\text { knowledge } \\
\text { about products), } \\
\text { outside shopping } \\
\text { area, customer } \\
\text { orientation is: } \\
\text { hospitality and } \\
\text { professionalism }\end{array}$ & $\begin{array}{l}2 \text { handhelds, } \\
\text { all year round, } \\
\text { inside and } \\
\text { outside. Inside } \\
\text { the handheld } \\
\text { is used as cash } \\
\text { desk system } \\
\text { only and not } \\
\text { for waiting } \\
\text { tables. Outside } \\
\text { the handheld } \\
\text { is used to take } \\
\text { orders at the } \\
\text { tables. }\end{array}$ & $\begin{array}{l}\text { Faster service at } \\
\text { large terrace }\end{array}$ & $\begin{array}{l}\text { Inside: separation } \\
\text { between host and } \\
\text { order preparation } \\
\text { (host takes and } \\
\text { delivers orders). } \\
\text { Outside: separation } \\
\text { of jobs between } \\
\text { palmtoppers and } \\
\text { runners. Job } \\
\text { rotation (but not } \\
\text { during a working } \\
\text { day) }\end{array}$ \\
\hline VI & Nijmegen & $\begin{array}{l}\text { Grand café } \\
\left(102 \mathrm{~m}^{2}\right) \text {, terrace } \\
\left(108 \mathrm{~m}^{2}\right) \text {, outside } \\
\text { shopping area, } \\
\text { drinks are more } \\
\text { important than } \\
\text { food. }\end{array}$ & $\begin{array}{l}5 \text { (old) } \\
\text { handhelds, } \\
\text { but only } 2 \\
\text { at a time are } \\
\text { being used by } \\
\text { experienced } \\
\text { staff (because } \\
\text { of coding), } \\
\text { during } \\
\text { summer, only } \\
\text { at terrace, } \\
\text { staff with little } \\
\text { experience } \\
\text { uses handhelds } \\
\text { when business } \\
\text { is slow }\end{array}$ & $\begin{array}{l}\text { Faster service } \\
\text { at large terrace, } \\
\text { reduction physical } \\
\text { work load }\end{array}$ & $\begin{array}{l}\text { Separation of } \\
\text { jobs between } \\
\text { palmtoppers and } \\
\text { runners, job rotation } \\
\text { (but not during a } \\
\text { working day) }\end{array}$ \\
\hline
\end{tabular}


Table 1 Overview of the cases in the study (continued)

\begin{tabular}{|c|c|c|c|c|c|}
\hline Case & Location & $\begin{array}{l}\text { Establishment } \\
\text { characteristics }\end{array}$ & Handheld use & Adoption reason & Job structure \\
\hline LU & Nijmegen & $\begin{array}{l}\text { Artplex } \\
\text { (combination } \\
\text { of lounge bar } \\
\text { and restaurant } \\
\text { with cinema, } \\
\text { theatre, music } \\
\text { and art) }\left(200 \mathrm{~m}^{2}\right) \text {, } \\
\text { terrace }\left(80 \mathrm{~m}^{2}\right) \text {, } \\
\text { in shopping area, } \\
\text { limited lunch and } \\
\text { dinner menu }\end{array}$ & $\begin{array}{l}3 \text { handhelds, } \\
\text { all year round, } \\
\text { inside and } \\
\text { outside, use } \\
\text { depends on } \\
\text { number of } \\
\text { clients and } \\
\text { time of day }\end{array}$ & $\begin{array}{l}\text { Faster service } \\
\text { at large terrace, } \\
\text { increased sales }\end{array}$ & $\begin{array}{l}\text { Separation of } \\
\text { jobs between } \\
\text { palmtoppers and } \\
\text { runners (but during } \\
\text { one year there were } \\
\text { integrated jobs), job } \\
\text { rotation (but not } \\
\text { during a working } \\
\text { day), runners are } \\
\text { allowed to take } \\
\text { orders for drinks }\end{array}$ \\
\hline VB & Nijmegen & $\begin{array}{l}\text { Pub }\left(100 \mathrm{~m}^{2}\right), \\
\text { terrace }\left(110 \mathrm{~m}^{2}\right) \text {, } \\
\text { in shopping area, } \\
\text { aims at student } \\
\text { customers in } \\
\text { evening }\end{array}$ & $\begin{array}{l}3 \text { handhelds, } \\
\text { all year round, } \\
\text { inside and } \\
\text { outside }\end{array}$ & $\begin{array}{l}\text { Faster service at } \\
\text { large terrace, tax } \\
\text { registration }\end{array}$ & $\begin{array}{l}\text { Separation of } \\
\text { jobs between } \\
\text { palmtoppers and } \\
\text { runners, job rotation } \\
\text { (even during a } \\
\text { working day), } \\
\text { runners are allowed } \\
\text { to take small orders } \\
\text { and enter into the } \\
\text { system at the cash } \\
\text { desk }\end{array}$ \\
\hline $\mathrm{LJ}$ & Utrecht & $\begin{array}{l}\text { Grand café } \\
\left(150 \mathrm{~m}^{2} ; 30 \text { tables) }\right. \\
\text { terrace (85 tables), } \\
\text { in shopping area, } \\
\text { no sport clothing } \\
\text { or mobile phones } \\
\text { allowed }\end{array}$ & $\begin{array}{l}10 \text { handhelds, } \\
\text { all year round, } \\
\text { inside and } \\
\text { outside, } \\
\text { palmtoppers and } \\
\text { runners carry } \\
\text { handheld }\end{array}$ & $\begin{array}{l}\text { Faster service at } \\
\text { large terrace }\end{array}$ & $\begin{array}{l}\text { Separation of jobs } \\
\text { between palmtoppers } \\
\text { and runners, job } \\
\text { rotation (every two } \\
\text { hours), runners are } \\
\text { allowed to take extra } \\
\text { orders at } \\
\text { delivering previous } \\
\text { orders }\end{array}$ \\
\hline
\end{tabular}

However, this does not necessarily mean that the jobs of palmtopper and runner are fixed positions. Task rotation is a normal phenomenon. Prior to a shift, tasks may be divided over the staff taking into account the work to be done and personal preferences. Task rotation is often practiced during shifts as well. This means that the division of labour is positional, not personal, i.e., different positions are created yet staff members normally rotate between these positions. It may be that newcomers are initially not given the palmtopper function and/or that the bar manager or the most senior employee work more often as palmtopper in the capacity of 'host', yet task rotation is the norm. This implies that lowering hourly labour costs is hardly an issue: staff are rewarded based on their age and experience, not necessarily based on the tasks conducted. Legal limitations to deploying juniors play a role here: staff under 18 years of age are prohibited from working with alcohol and working later than 23.00 hours. These regulations impede deploying juniors. As saving labour costs seems hardly an issue, the question arises what then accounts for the new division of labour that is almost always realized. 


\subsection{Adoption reasons}

The answer lies in the dominant reason for adopting handhelds: speed of delivery. This was mentioned as the main or even only reason for adoption in all establishments. Additional reasons were the generic term 'efficiency' and 'improved service' but also 'preventing theft' (case DC) respectively "control over giving away free drinks" (case VA), a modern image (case VA), "physically less demanding work for employees" (cases VI and LF), 'registration for revenue' (case VB), 'imitating competitors' (case EN) and a shorter instruction time, presumably for the runner (case D). Faster delivery may result in a higher table turnaround: customers get served more quickly and may either leave more quickly freeing the table for new customers, or use the opportunity to drink more during their stay. Total sales may thus increase, as some establishments reported.

The importance of speed of delivery warrants a closer look at the implications for the work process. A higher speed of delivery is more easily realized when the tasks of taking and delivering orders are split: the order-taker does not first have to go to the bar to fetch the consumptions, but a separate 'runner' can bring it to the table. The advantage becomes larger when one realizes that waiters normally took orders at several tables before walking to the bar. An increased speed is also realized when a handheld-equipped waiter also delivers the drinks, as the orders reach the bar immediately upon entering them in the handheld. Working with runners further increases this speed, however. Two establishment managers reported that this option may actually increase labour costs as more staff is sometimes needed when separate runners are deployed: one additional person needs to be available.

\subsection{The cyclic nature of the business}

During operation hours changes may take place as well. Both during the day and between seasons, there are peaks in the workload. During lunch and dinner time it tends to be busy, while during other opening times few customers tend to be present. In addition, terraces may be stamped when the weather is favourable. This variation has an impact on the chosen job structure and on task allocation. The bars tend to have permanent as well as temporary employees. The latter are hired when it is busy. They are the less experienced and tend to get the more mundane tasks. Applied to the division of labour, most of the time they are the runners delivering the consumptions to the tables (often at outdoor terraces in the warmer seasons). Thus, when it is busy (a) the division between palmtopper and runner is introduced and (2) the runner job is assigned to less qualified staff.

The simple nature of most tasks makes these interchangeable. With a low c.q. virtually absent 'learning hurdle' (Benders, 1993, p. 14), tasks may easily be taken over from one employee by the other. This derives the notion of 'job rotation' of much of its meaning: different jobs do not exist because of differences in the requisite skills to perform tasks, yet because splitting the tasks of taking and delivering orders allows faster delivery. In the investigated establishments, task rotation occurs very fluidly: waiting staff tend to take over tasks from each other quite easily.

Bars aim to limit the investment in handhelds and thus tend to keep their numbers low. This affects the division of labour. When it gets busy the number of employees may be increased, but only a few can be provided with a handheld. In that case, a split between palmtopper and runners results automatically. 


\subsection{The exceptions: integrated jobs}

It is interesting to take a closer look at the three exceptions to the rule. One case is a combined bar - restaurant (case H), the other a large bar with extensive outdoor seating (case L) and the third case LJ owns the comparably high number of ten handhelds.

Case $\mathrm{H}$ started as a micro brewery, which was gradually extended with other functions including a restaurant. The bar annex brewery and the restaurant use the same information system. The company positions itself as a quality establishment, with a staff that is knowledgeable about its products, notably its home-brewed beers. In addition, a friendly customer approach is advocated. Initially, management hesitated to introduce handhelds because of fears that they might take much attention of the waiting staff at the expense of time for the customer (cf. Gerpott and Kornmeier, 2009). This is still a concern, although the handhelds were implemented as early as July 2006. The handhelds are used throughout the year. Interestingly, one handheld has developed into a substitute cash register as a full-fledged PC for this purpose would have been roughly three times as expensive as a handheld. All restaurant orders are now processed via the handheld, which is, however, not used at the tables. Instead, it lies at the entrance: waiters take the orders at the table and then walk to the handheld at the entrance to feed the system. In the bar, there is a full-fledged PC cash point and the second handheld is not used except when the outdoor terrace is open. In that case, the handheld is used at the tables on the outdoor terrace. However, the two handhelds are not always sufficient when it is busy. In this case, the waiting staff without handhelds de facto become runners. They take orders, but pass these to the palmtoppers.

In case L, a bar with a large outdoor terrace, the handhelds were introduced in 2002 as an extension to the existing information system. The tasks were initially divided over palmtoppers and runners: the idea was to serve the customers as quickly as possible. Initially, payment was required when ordering and the consumptions were brought later. Mistakes were made and the waiting staff received complaints, also about the early payment. In addition, the waiters found it unpleasant just to serve, i.e., go forth and back to tables and the bar. The staff was relatively stable. Staff involvement, fed by customer complaints, lead to a change in the existing division of labour: the former runners also got handhelds, so that the integrated waiter's jobs were re-installed. The new waiters had their own 'districts' at the terrace, just like they had before the handheld was introduced. The reversal was motivated by the desire to keep the customers happy. With change of management, however, the split between palmtoppers and runners was re-installed. The new management gives preference to the more efficient way of serving customers. To keep customers happy, however, customers can now pay afterwards and runners can now take orders too. This whole system is explained to the customers on a table card.

An interesting feature of case LJ is the high number of handhelds. Where most establishments tend to have a limited number (two to five) available, in case LJ there were ten. As elsewhere, they operate a system with runners and palmtoppers, yet the runners carry a handheld as well. The idea is that customers pass their orders to palmtoppers who are constantly at the outdoor terrace and that the orders are carried outdoors by runners, preferably 'within a minute'. However, it often occurs that customers at a specific table ask for additional items when their order is delivered. To avoid waiting times, the runner may than take orders as well. An additional yet less important reason is to prevent the impression that customers are not well served. Thus, in this case the runners act as a kind of additional, yet non-standard, ordering point. Remarkably, if they do so their jobs may be seen as more 
complete than the 'palmtoppers'. Finally, those assigned the runner and palmtopper jobs switch every two hours to avoid runners becoming physically overburdened.

\section{Conclusion}

The introduction of new technical systems often affects the existing job structure. A new technical system influences the task pool, eliminating certain often manual tasks while creating operating tasks. In the case of handheld computers in bars and restaurants, the processing of order data is automated: orders are passed immediately to the bar c.q. kitchen upon being entered into the handheld, bills may be generated automatically and all financial and tax related excise data are stored in the financial modules. In principle, this may leave the conventional waiter's job virtually unaffected: the only change would be that waiters no longer have to go in person to the bar to have the orders prepared. However, with few exceptions the introduction of the handheld led to a separation of the (previous) waiter's job into 'palmtoppers' (those operating the handhelds) and 'runners' (those delivering orders).

This split is 'technology enabled': the new technical system made it likely that these previously combined tasks are now generally separated. Whilst in principle such a separation is possible without handhelds, this hardly occurs as it is usually deemed inefficient. Although the economic gain is not realised through decreased labour costs, but rather through increased speed of delivery, resulting in higher turnaround, the handheld makes this new division of labour a much more attractive option to enact. However, we also found evidence that there is still the possibility to choose (managerial discretion) and sometimes integrated jobs were maintained c.q. re-installed. This happened at three establishments because of, respectively, a strategic view on its market positioning (high-end) and for employee and customer reactions (complaints).

The picture emerges that an increased division of labour is the default option after handhelds have been introduced. The alternative of having an integrated waiting job is possible, yet only realized in a minority of cases. However, when business is slow this becomes the normal option: the division of labour is thus adapted in function of the needed labour capacity. Analytically, the division of labour at a given point depends on:

- the level of business activity

- the number of handhelds relative to the number of waiting staff deployed.

If there are sufficient handhelds available, all staff may be provided with this. The busier it becomes, the less likely that this condition is fulfilled. In addition, the number of handhelds tends to be limited. Yet even when all staff carry their own handhelds, a specific order is normally brought by another person than the one taking the order. In praxis, the implementation of handhelds has indeed played a higher division of labour into the hand. The technology-enabled job separation is clearly a dominant logic.

The conceptual implication of our study is that the division of labour after the introduction of a new technical system is contingent on a variety of (sometimes interacting) factors. The economic motivation for using the technology and contextual factors play a role in deciding what job structure results in what circumstances. Even in the simple case of handhelds in the hospitality industry, many factors play a role. Any study investigating relationships between a technical system and job-related features must take such factors into account. 
Whereas qualitative statistical studies show correlations between the introduction of new technologies and job related aspects, but fail to pinpoint the underlying mechanisms, this study explains the conditions why certain choices prevail and that alternative choices are possible. Our results indicate that it is advisable to include the characteristics of the job structure and the technology-in-use in future quantitative research, rather than to settle for just the presence of job structures or technology.

In addition, future research should address the organisational changes that go along with the technological developments. As pointed out repeatedly (Bask et al., 2011; Nyangosi et al., 2009; Olaniyi et al., 2010), technological systems evolve rapidly. This also holds for the number of user options on handhelds and therewith their potential in work settings. For instance, the availability of camera's allows to record events on the spot, opening possibilities for additional services to customers but also to document customer misbehaviour (theft; leaving without paying). Such additional options have consequences for the task pool and thus the division of labour.

A methodological limitation of this study entails that we did not conduct comparative research between establishments with and without handhelds. This raises the question whether establishments without handhelds use an integrated or separated job structure. However, since we investigated whether the job structure changed with the introduction of the handheld, we are confident that our results hold in a comparative research.

For decision makers and managers - in hospitality industry and elsewhere - our results indicate that the introduction of certain technological devices does influence the division of labour, albeit indirectly. There is always room for choosing a job structure that best fits the organisation's goals or specific characteristics. This study presents some of the conditions that might influence those choices.

\section{References}

Barley, S.R. and Kunda, G. (2001) 'Bringing work back in', Organization Science, Vol. 12, No. 1, pp. 76-95.

Bask, A., Merisalo-Rantanen, H., Tinnila, M. and Lauraeus, T. (2011) 'Towards e-banking: the evolution of business models in financial services', International Journal of Electronic Finance, Vol. 5, No. 4, pp. 333-356.

Bayerl, P.S. (2010) The role of technology in distributed team coordination. A multi-method investigation of a technology change process in the field, PhD thesis, Delft University of Technology, Delft, The Netherlands.

Benders, J. (1993) Optional Options: Work Design and Manufacturing Automation, Avebury, Aldershot.

Bouwman, H. and Van de Wijngaert, L. (2009) 'Coppers context and conjoints: a reassessment of TAM', Journal of Information Technology, Vol. 24, No. 2, pp. 186-201.

Caus, T., Christmann, S. and Hagenhoff, S. (2009) 'Development of context-aware mobile services: am approach to simplification', International Journal of Mobile Communications, Vol. 7, No. 2, pp. 133-153.

Davis, L.E. and Taylor, J.C. (1976) 'Technology, Organization and Job Structure', in R. Dubin (Ed.): Handbook of Work Organization and Society, Rand McNally College Publishing, Chicago, pp.379-419.

De Ruijsscher, C. and Victoria, H. (2006) 'Tijd voor techniek op het terras? Een onderzoek naar de redenen die aanbieders van handhelds aandragen op het Internet', Paper course Technologie, Arbeid en Organisatie, Radboud University Nijmegen, Nijmegen, The Netherlands. 
Gerpott, T.J. and Kornmeier, K. (2009) 'Determinants of customer acceptance of mobile payment systems', International Journal of Electronic Finance, Vol. 3, No. 1, pp. 1-30.

Grint, K. and Woolgar, S. (1997) The Machine at Work; Technology, Work and Organization, Polity Press, Cambridge.

Hacker, W. (1989) 'Vollständige vs. unvollständige Arbeitstätigkeiten', in: S. Greif, H. Holling and N. Nicholson (Eds.): Arbeits- und Organisationspsychologie, Psychology Verlags Union, Munich, pp. 463-466.

Karasek, R.A. (1979) 'Job demands, job decision latitude and implications for job redesign', Administrative Science Quarterly, Vol. 24, No. 7, pp. 285-307.

Lingfen, C., Woods, D., Curran, K. and Doherty, J. (2010) 'Mobile development environments for electronic finance', International Journal of Electronic Finance, Vol. 4, No. 2, pp. 99-119.

Myers, B.A. (2005) 'Using handhelds for wireless remote control of PC's and appliances', Interacting with Computers, Vol. 17, No. 3, pp. 251-264.

Nyangosi, R., Arora, J.S. and Singh, S. (2009) 'The evolution of e-banking: a study of Indian and Kenyan technology awareness', International Journal of Electronic Finance, Vol. 3, No. 2, pp. 149-165.

Olaniyi, O.M., Ajose, S.O. and Adegoke, M.A. (2010) 'Development of a mobile airline reservation and payment system', International Journal of Electronic Finance, Vol. 4, No. 4, pp. 372-389.

Orlikowski, W.J. and Scott, S.V. (2008) 'Sociomateriality: challenging the separation of technology, work and organization', Academy of Management Annals, Vol. 2, No. 1, pp. 433-474.

Scornavacca, E., Prasad, M. and Lehmann, H. (2006) 'Exploring the organizational Impact and perceived benefits of wireless personal digital assistants in restaurants', International Journal of Mobile Communications, Vol. 4, No. 5, pp. 558-567. 